\title{
Marital Satisfaction: An Analysis of Long Distance Marriage Couples
}

\author{
Bramana Nanditya Putra ${ }^{1}$, Afdal $^{2}$ \\ ${ }^{12}$ Universitas Negeri Padang \\ *Corresponding author, e-mail: afdal@konselor.org
}

\begin{abstract}
This research aims to describe marital satisfaction of long distance marriage and and the difference marital satisfaction between husband and wife undergoing long-distance marriages (LDM). This research was a comparative research with a sample number of 45 couples who have LDM. Sample collection withdrawal technique using a purposive sampling technique. This research was measured using a Marital Satisfaction Inventory developed from ENRICH Marital Satisfaction Scale with a few adjustments. The research findings reveal that: (1) marital satisfaction of husband undergoing longdistance marriages is generally in medium category with a percentage of $70.25 \%$, (2) marital satisfaction of wives undergoing LDM is generally in the high category with a percentage of $74.65 \%$, and (3) there is no difference in marital satisfaction between husband and wife undergoing LDM with the value $F$ of 4,940 with probability 0.029 smaller than 0.05 .
\end{abstract}

Keywords: Marital satisfaction, Couples, Long Distance Marriage.

How to Cite: Putra, B.N., Afdal, A. (2020). Marital Satisfaction: An Analysis of Long Distance Marriage Couples. International Journal of Research in Counseling and Education. 4 (1): pp. 64-69, DOI: $10.24036 / 00287 z a 0002$

\section{Introduction}

Marriage is a cycle of human life based on a legal commitment with an emotional bond between two people (men and women) to share physical and emotional intimacy, share responsibilities, and source income (Ardhianita \& Andayani, 2013; Rachmawati \& Mastuti, 2013), the fulfillment of developmental duties (Hurlock, 2002) and forms a happy household and family (Amelia et al., 2018). Every couple must crave happiness and satisfaction in marriage (Handayani \& Harsanti, 2017; Afdal, et. Al. 2019). Wedding satisfaction is something that is sought and expected by every married couple. Besides, the satisfaction of the marriage can be interpreted as a mental condition describing a person's perception of the advantages and disadvantages of a marriage (Bradbury et al ., 2000), coveted by everyone (Nawaz et al., 2014) and determined by a couple to be able to feel the satisfaction of the marriage by meeting each other's physical, economic, emotional, and 2014 psychological need's satisfaction in marriage can be interpreted as a degree where the individual feels satisfied with his relationship and is a strong indicator for the success of a relationship (Anderson \& Emmers-Sommer, 2006). Azeez (2013) reveals that a feeling of pleasure may arise based on a subjective evaluation of the overall quality of the marriage, in the form of fulfilling the needs, hopes, and desires of the spouses in a marriage. Furthermore, the most important component in marriage satisfaction is love, intimacy, commitment, and passion is also a positive thing in marriage satisfaction. If these three things can be combined well, then the satisfaction at the wedding will be obtained (Carandang \& Guda, 2015). In fact, not all couples could achieve satisfaction in marriage (Larasati, 2012), realizing a happy, quiet, peaceful, and eternal family (Rozalinda \& Nurhasanah, 2014). Many couples choose divorce if experiencing problems in marriage (Amelia et al., 2018; Afdal et.al., 2019) to build a happier new life (Harahap \& Lestari, 2018).

Padang is one of the cities that have the highest divorce rate in West Sumatera during 2017 "that is as 1,374 cases of lawsuit from husband to wife (Asyari, 2018). In 2018, it recorded a total of 1507 divorce cases from 5,190 total family head or can be centered at $29.03 \%$. Even the increase in the year 2019 is as many as 2,063 cases of divorce (Padang, 2019). Furthermore, Widyanisa et al., (2018) mention that one of the causes of divorce is a couple who undergo long-distance marriage (LDM). LDM is a condition where couples live in 
different locations during weekdays sometimes for a long time in the interest of the couple's career (Mcbride \& Bergen, 2014) or parted physically after marriage (Pistole et al., 2010) Even children because of demands of life in the modern era (Mijilputri, 2015; Purwanto et al., 2018; Widyanisa et al., 2018). In addition, longdistance marriage is a very difficult error for some people who will be living (Prameswara \& Sakti, 2016), and most suffer from household problems (Rachmawati \& Mastuti, 2013) because there is no fulfillment of the needs of the common (Fatimah, 2018).

\section{Method}

This research was a comparative descriptive research. This study was conducted against 45 married couples who have long-distance marriage in Padang City. The sample has been undergoing marriage for \pm 1 year to \pm 10 years and undergoes long-distance marriage \pm 1 month until \pm 3 years, with meeting time once a week even once a month which profession as a lecturer, teacher, TNI, POLICE, nurse, government civil servant/STATE/private employee, and self-employed/merchant. This research measures is Marital Satisfaction Inventory of which include (a) personality issue, (b) communication, (c) conflict resolution, (d) financial management, (e) leisure activities, (f) sexual relationship, (g) hildren and parenting, (h) children and parenting, (i) equalitarian roles, and (j) religious orientation developed from ENRICH Marital Satisfaction Scale with a few adjustments. The data-collection tool used in this research was a poll-shaped model with Likert scale with a 35-item statement with a choice of answers from strongly agreed (if the item is positive with a score of 5 and if the negative item with a score of 1 ), agree (if the item is positive with a score of 4 and if the item is negative with a score of 3), Disagree (if the item is positive with a score of 2 and if the item is negative by a score of 4), and strongly disagree (if the item is positive 1 and if the item is negative by a score of 5). The analysis of data in this study used a descriptive analysis of the percentage formula and analysis of one-way ANOVA to identify the difference in marriage satisfaction husband who has a long-distance marriage with the wife who has long-distance marriage. The categorizing of wedding satisfaction in this study is high ( $\geq 128.33$ or $\geq 73.33 \%$ ), moderate ( $81.66-128.32$ or $46.66 \%-73.32 \%$ ), and low ( $\leq 81.65$ or $\leq$ 46.65\%).

\section{Results and Discussion}

Based on the results of data processing, the results of this study can be described on Table 1. From table 1 it can be seen that in general, marital satisfaction of husbands who have long-distance marriage belongs to the category of the medium while the general satisfaction of marriage wives who have long-distance marriage belongs to the high category. Based on table 1 above, it can be seen that the high level of marital satisfaction of wives who have long-distance marriage lies in the oriental religious indicators. Religious oriental is the meaning of religious beliefs and how it is performed in everyday life (Fowers \& Olson, 1993). Therefore, to maintain her marriage relationship, the wives who have long-distance marriage increase their religious beliefs and the meaning of religion. Such as optimizing the worship together at home, avoiding desperate attitudes if experiencing problems in the household, or trying to think positively in resolving the problems of the household and always happy or receive advice given by couples related to worship. The results of the study were also in line with the results of research conducted by (Sullivan, 2001; Dowlatabadi et al., 2013) suggested that a person's religious level would affect marital satisfaction. Because the values embraced in religion became one of the sources to find a solution to marriage (Balkanlioglu, 2013). The religion that is balanced by a person will make the person internalize the religious values into how to think, behave, and behave (Fincham, 2008; Fincham et al., 2011). It is explained that religion is one aspect of the wife who has long-distance marriage to feel the satisfaction of marriage.

The husband marital satisfaction who has long-distance marriage lies in the indicator of children and parenting, which is an aspect related to the attitude and feelings about owning and raising children (Fowers \& Olson, 1993). Based on the results of the study that the husband who have long-distance marriage achieve satisfaction in the marriage is after having a child or togetherness created because given the new responsibilities about educating and discipline his fruit. The results of the research are done in line with the research results of Mardiyah (2018) which reveals that the presence of children provides a positive effect on the family and can bring happiness and pride to the couple. Child absence affects the satisfaction of marriage means the satisfaction of the marriage has not been perfect without a child's presence (Mardiyan \& Kustanti, 2016). It is explained that the presence of children is one aspect of the husband who has long-distance marriage feels the satisfaction of marriage. 
Table 1

Marital Satisfaction of LDM Couples

$\mathrm{n}=90$

\begin{tabular}{|c|c|c|c|c|c|c|c|c|c|}
\hline \multirow{2}{*}{ Variable } & \multirow{2}{*}{ Indicators } & \multicolumn{2}{|c|}{ Mean } & \multicolumn{2}{|c|}{ SD } & \multicolumn{2}{|c|}{$\%$ Mean } & \multicolumn{2}{|c|}{ Category } \\
\hline & & Husband & Wife & Husband & Wife & Husband & Wife & Husband & Wife \\
\hline & $\begin{array}{l}\text { Persona- } \\
\text { lity Issue } \\
\text { (2) }\end{array}$ & 6,96 & 7,53 & 1,46 & 1,59 & 69,56 & 75,33 & Medium & High \\
\hline & $\begin{array}{l}\text { Communi- } \\
\text { cation (4) }\end{array}$ & 12,71 & 14,67 & 2,97 & 2,65 & 63,56 & 73,33 & Medium & High \\
\hline & $\begin{array}{l}\text { Conflict } \\
\text { Resolution } \\
\text { (4) }\end{array}$ & 13,24 & 14,24 & 2,87 & 3,45 & 66,22 & 71,22 & Medium & Medium \\
\hline & $\begin{array}{l}\text { Financial } \\
\text { Manage- } \\
\text { ment (4) }\end{array}$ & 15,07 & 16,07 & 2,75 & 2,96 & 75,33 & 80,33 & High & High \\
\hline & $\begin{array}{l}\text { Leisure } \\
\text { Activities } \\
\text { (4) }\end{array}$ & 12,53 & 12,49 & 3,24 & 3,18 & 62,67 & 62,44 & Medium & Medium \\
\hline \multirow[t]{5}{*}{$\begin{array}{c}\text { Marital } \\
\text { Satisfac- } \\
\text { tion }\end{array}$} & $\begin{array}{l}\text { Sexual } \\
\text { Relation- } \\
\text { ship (2) }\end{array}$ & 6,93 & 6,76 & 1,44 & 1,55 & 69,33 & 67,56 & Medium & Medium \\
\hline & $\begin{array}{l}\text { Children } \\
\text { and } \\
\text { Parenting } \\
(4)\end{array}$ & 15,36 & 16,31 & 2,96 & 2,75 & 76,78 & 81,56 & High & High \\
\hline & $\begin{array}{l}\text { Family and } \\
\text { Friends (3) }\end{array}$ & 10,42 & 11,24 & 2,56 & 2,11 & 69,48 & 74,96 & Medium & High \\
\hline & $\begin{array}{l}\text { Equalita- } \\
\text { rian Roles } \\
\text { (4) }\end{array}$ & 14,4 & 14,64 & 3,05 & 2,66 & 72 & 73,22 & Medium & Medium \\
\hline & $\begin{array}{l}\text { Religious } \\
\text { Orienta- } \\
\text { tion 4) }\end{array}$ & 15,31 & 16,69 & 2,42 & 2,39 & 76,56 & 83,44 & High & High \\
\hline Overall & (35) & 122.93 & 130.64 & 17.09 & 15.08 & 70.25 .00 & 74.65 & Medium & High \\
\hline
\end{tabular}

Furthermore, the difference in the high satisfaction of the marriage is perceived by the wife who has longdistance marriage to the satisfaction of the marriage that is felt by the husband who has long-distance marriage is located on the personality aspects of the issue, communication, and family and friends. But a fundamental difference in marriage satisfaction between husband and wife lies in the communication indicator or it can be concluded that the wife is better able to create and build communication than the husband despite having a long-distance marriage. With communication through openness in various aspects, the wife felt the satisfaction in her marriage despite having a long-distance marriage. The results of the study in line with the opinion Peplau \& Gordon (Santrock, 2002) said the wife is more open than the husband. Women usually express tenderness, fear, and sadness than men. Furthermore, the results of the study were in line with the results of the study (Dindia \& Allen, 1992) also revealed based on the research he did against the 205 research subjects that relate gender with the problem of openness shows that when having an 
intimate relationship with others then in communicating, women will be more open to revealing things that are personal than men. In other words, women were more expressive and open in communicating everything that he experiences (Rini, 2009). Then it can be concluded that the difference in the marital satisfaction of married couples who have long-distance marriage lies in how high the level of communication skills created by the couple.

Further results from the processing of wedding satisfaction data of the husband-wife who have longdistance marriage through analysis one-way anova can be seen in Table 2 as follows.

Table 2

Difference in Marital Satisfaction of LDM Couples

$\mathrm{n}=90$

\begin{tabular}{|c|c|c|c|}
\hline \multicolumn{4}{|c|}{ Test of Homogeneity of Variances } \\
\hline \multicolumn{4}{|c|}{ Marriage satisfaction } \\
\hline Levene Statistic & df1 & $\mathrm{df} 2$ & Sig. \\
\hline .723 & 1 & 88 & .397 \\
\hline
\end{tabular}

Table 3

\begin{tabular}{|l|r|r|r|r|r|}
\hline \multicolumn{7}{|c|}{ ANOVA } \\
\hline Marital satisfaction & Sum of Squares & df & Mean Square & F & \multicolumn{1}{c|}{ Sig. } \\
\hline Between Groups & 1337.878 & 1 & 1337.878 & 4.940 & .029 \\
\hline Within Groups & 23833.111 & 88 & 270.831 & & \\
\hline Total & 25170.989 & 89 & & & \\
\hline
\end{tabular}

Table 3 shows that from the test of homogeneity of variances sig value of 0397 which means greater than $0.05(0397>0.05)$ Then this means the population group variant is homogeneous. Thus the requirements of homogeneity for comparative analysis are fulfilled.

From the results of data analysis obtained $\mathrm{F}$ value of 4,940 with a probability 0.029 when compared to 0.05 , the value of probability was smaller which means there was a significant difference in marital satisfaction between husbands who have a long-distance marriage with wives who have a long-distance marriage. So the hypothesis is put forward (H1: There was a significant difference between the satisfaction of the marriage of the husband who has a long-distance marriage with the satisfaction of a wife's marriage through long-distance marriage) received.

\section{Conclusion}

This research shows that long-distance marriage does not affect the marriage satisfaction of married couples. Based on the results obtained in general the satisfaction of the marriage husband who has longdistance marriage belongs to the category of the medium, in general, the satisfaction of marriage wife who has long-distance marriage belongs to the high category. The marriage satisfaction of the wife in longdistance marriage lies in the high and low religious oriental. While the husband who has long-distance marriage feels the satisfaction of marriage after getting children or become parenting. The results of the study also showed that more communication was done by wives than husbands. Wives are more frequent communication, even they are easier and comfortable to be open in a variety of things either feelings, concerns, or problems that occur in the family than the husband. So this shows the difference in marital satisfaction perceived by couples who have a long-distance marriage.

Based on the research results, it is advised to hoped that couples who have long-distance marriage to create communication in maintaining the satisfaction of marriage with long-distance marriage life such as open each other either feeling, attention, or problems occurring in the family or avoiding ineffective communication. Further research needs to be done related to the satisfaction of married couples who have long-distance marriage reviewed from communication.

\section{References}

Afdal, A., Arnaldi, A., Nirwana, H., Alizamar, A., Zikra, Z., Ilyas, A., \& Fikri, M. (2019, December). Increasing Life Satisfaction of Domestic Violence Victims through the Role of Supporting Group Therapy on Social Media. In International Conference on Education Technology (ICoET 2019). Atlantis Press.

Afdal, A., Wulandari, E., \& Nirwana, H. (2019, July). PREMARITAL COUNSELING: OPPORTUNITIES AND 
CHALLENGES IN THE ERA OF INDUSTRIAL REVOLUTION 4.0. In International Conference on Educational Technology.

Amelia, R., Abidin, M. Z., \& Riskasari, W. (2018). The relationship between self disclosure and religiusity with the commitment of marriage to the wife of the NAVY's sailor. The Journal of Psychology of POSEIDON: scientific Journal of Marine Psychology-the Modernism,12(1), 25-35.

Anderson, T. L., \& Emmers-sommer, T. M. (2006). Predictors of relationship satisfaction in online romantic relationships predictors of relationship satisfaction in online romantic relationships. Communication Studies, 57(2), 153-172. https://doi.org/10.1080/10510970600666834

Ardhianita, L., \& Andayani, B. (2013). Wedding satisfaction is reviewed by dating and not dating. Journal of Psychology, 32(2), 101-111.

Asyari. (2018). A year in Padang there was 2 thousand new widows. Jawa Pos.

Azeez, A. (2013). Employed women and rarital satisfaction: A study among female nurses. International Journal of Management and Social Sciences Research (IJMSSR), 2(11), 17-22.

Balkanlioglu, M. A. (2013). Questioning the relationship between religion and marriage: practice of, perception of, and attitudes towards religion and $\mathrm{m}$. The Journal of International Social Research, 7(31), 515-523.

Bradbury, T. N., Fincham, F. D., \& Beach, S. R. H. (2000). Research on the nature and determinants of marital satisfaction: A decade in review. Journal of Marriage and the Family, 62(November), 964-980.

Carandang, M. N. S., \& Guda, I. V. P. (2015). Indicators of marital satisfaction of batangueñ o couples: Components of love and the other external factors in marriage. International Journal of Iiformation and Education Technology, 5(1). https://doi.org/10.7763/IJIET.2015.V5.477

Dindia, K., \& Allen, M. (1992). Sex differences in self-disclosure: A meta-analysis sex differences in selfdisclosure: A meta-analysis. Psychological Bulletin, 112(1), 106-124. https://doi.org/10.1037/00332909.112.1.106

Dowlatabadi, F. H., Saadat, S., \& Jahangiri, S. (2013). The relationship between religious attitudes and marital satisfaction among married personnel of departments of education in rasht city , Iran. International Journal of Advanced Studies in Humanities and Social Science, 1(6), 608-615.

Fatimah, S. (2018). Relationship of love commitment with marital satisfaction moderated by the abundance. Psikodimensia, 17(1), 26-35.

Fincham, F. D. (2008). Spiritual behaviors and relationship satisfaction: A critical analysis of the role of prayer. Journal of Social and Clinical Psychology, 27(4), 362-388.

Fincham, F. D., Ajayi, C., \& Beach, S. R. H. (2011). Spirituality and marital satisfaction in African American couples. Psychology of Religion and Spiritual, 3(4), 259-268. https://doi.org/10.1037/a0023909

Fowers, B. J., \& Olson, D. H. (1993). ENRICH marital satisfaction scale: A brief research and clinical tool. Journal of Familiy Psychology, 7(2), 176-185.

Handayani, N. S., \& Harsanti, I. (2017). Wedding satisfaction: The study of the influence of working-family conflicts in women. Jurnal Psikologi, 10(1), 92-99.

Harahap, S. R., \& Lestari, Y. I. (2018). The role of commitment and interpersonal communication in enhancing the marital satisfaction of husbands who have wives work. Jurnal Psikologi, 14(2), 120-128.

Hurlock, E. B. (2002). Developmental psychology (an approach throughout life span). Erlangga.

Larasati, A. (2012). Marital satisfaction in wives is reviewed from the involvement of husbands in the face of economic demands and division of role in households. Journal of Education and Developmental psychology, 1(3), 1-6.

Lavner, J. A., Kamey, B. R., \& Bradbury, T. N. (2014). Relationship problems over the early years of marriage: Stability or change? Journal of Family Psychology, 28(6), 979-985.

Mardiyah, U. (2018). The difference in marriage satisfaction husband from wife working based on self openness factor.

Mardiyan, R., \& Kustanti, E. R. (2016). The satisfaction of marriage in a spouse who has no offspring. Empati Journal, 5(3), 558-565. 
Mcbride, M. C., \& Bergen, K. M. (2014). Voices of women in commuter marriages : A site of discursive struggle. $\begin{array}{llll}\text { Journal of Sosial and Personal Relationships, 31(4), 554-572. } & \text {. }\end{array}$ https://doi.org/10.1177/0265407514522890

Mijilputri, N. (2015). The role of social support to lonely wives who undergo Long distance marriage. EJournal.psikologi.fisip-Unmul.ac.id, 3(2), 477-491.

Nawaz, S., Javeed, S., Haneef, A., Tasaur, B., \& Khalid, I. (2014). Perceived social support and marital satisfaction among love. International Journal of Academic Research and Reflection, 2(2), 41-50.

Padang, P. A. (2019). Divorce rate report in Padang City.

Pistole, M. C., Roberts, A., Chapman, M. L., Pistole, M. C., \& Chapman, M. L. (2010). Journal of social and personal. Journal of Sosial and Personal Relationship, 27(4), 535-552. https://doi.org/10.1177/0265407510363427

Prameswara, A. D., \& Sakti, H. (2016). Long Distance Marriage. Empati Journal, 5(3), 417-423.

Purwanto, B., Arisanti, I., \& Atmasari, A. (2018). Long distance marriage with working stress on employees of PT Wijaya Karya (PERSERO) TBK (Project of gas engine power plant 50 MW Sumbawa). Psimawa Journal, 1(2000), 26-29.

Rachmawati, D., \& Mastuti, E. (2013). The difference in marital satisfaction rate is reviewed from the degree of marriage adjustment to the wife of Brigif 1 Navy - AL, who underwent long distance marriage. Journal of Education and Developmental psychology, 2(2), 73-80.

Rini, R. I. R. S. (2009). The relationship between self-disclosure and marriage adjustments to married couples living separately. Psycho Idea, 7(2), 1-13.

Rozalinda, \& Nurhasanah. (2014). Perception of the women in Padang city about divorce. MIQOT, XXXVIII(2), 395-416.

Santrock. (2002). Life Span Development. Alih bahasa: Achmad Chusairi dan Juda Damanik. Erlangga.

Sullivan, K. T. (2001). Understanding the relationship between religiosity and marriage : An investigation of the immediate and longitudinal effect of religiosity on newlywed couples. Journal of Family Psychology, 15(1), 610-626.

Widyanisa, A., Lubis, H., \& Sary, K. A. (2018). The pattern of interpersonal communication on married couples who undergo long distance marriage. E-Journal of communication Sciences, 6(4), 385-397. 